\title{
A new species of Bosminopsis \\ (Crustacea, Cladocera) from the Rio Negro(*)
}

\section{Gerd-Oltmann Brandorff ${\left({ }^{* *}\right)}^{*}$}

\author{
Abstract \\ It is described a new species Bosminopsis \\ negrensis from the lower Rio Negro.
}

\section{INTRODUCTION}

Only a single species of Bosminopsis, B. deitersi, is known. According to Hutchinson (1967) it "tends to be warm temperate to tropical". In South America it was originally described by RICHARD (1895) from the Rio de La Plata, Argentina. Later it was also found in Mato Grosso, Brazil by DADAY (1903) and in the delta of the Amazon river (Stingelin, 1904). As the sampling of the author shows, B. deitersi is a common plankter in the black waters of the Amazon basin. In the same type of water was found Bosminopsis negrensis.

\section{DESCRIPTION}

Generally seen $B$. negrensis is very similar to the long known $B$. deitersi. The striking difference is the long posterior spine of $B$. negrensis which reminds of some Daphnia.

THE FEMAle heAd (Fig. 1, 1; Fig. 5).

The head is indented above the eye (the socalled supra-ocular depression). There is a prolonged rostrum on which inserts the first antenna. The rostrum and te antennules are curved caudad, the tip of the antennule points downward. Rostrum and antennules are studded with short spinules, which on the rostrum stand in a row whereas on the antennules are irregular. At the end of the first antenna there are long, straggling, olfactory setae like in $B$. deitersi. The surface of the head is reticulated. The labrum is big, the lower part bears fine hairs.

The second antenna consists of a large basipod. an endopod of three segments and an exopod of three segments. The basipod has one sensory seta that originates near the base of the segment. The first two segments of the second antennal endopod each bear one long swimming seta while the third segment has three. The exopod has only three swimming setae on the distal segment.

THE BODY SHELL

The body shell is rounded trapezoidal with the greater width cranial and the smaller caudal. On the ventro-caudal margin of the sheil are two setae of about $50 \mu \mathrm{m}$ length and a short spinule. In the dorso-posterior corner of the shell originates a long spine which is studded with short spinules. Only the first fifth of the posterior spine lacks these spinules. The length of the spine is about $3 / 4$ of the length of the animal.

\section{POSTABDOMEN (Fig. 2)}

The postabdomen is elongated and ends with the distal claws. There are one or two rows of four spinules and two rows of short hairs. On the basis of the claws is a large spine.

(*) - Cooperation between Max-Plank-Institut and INPA.

("*) - Max-Planck-Inst. of Limnology, Dep. Tropical Ecology, 23Plön, Germany. 

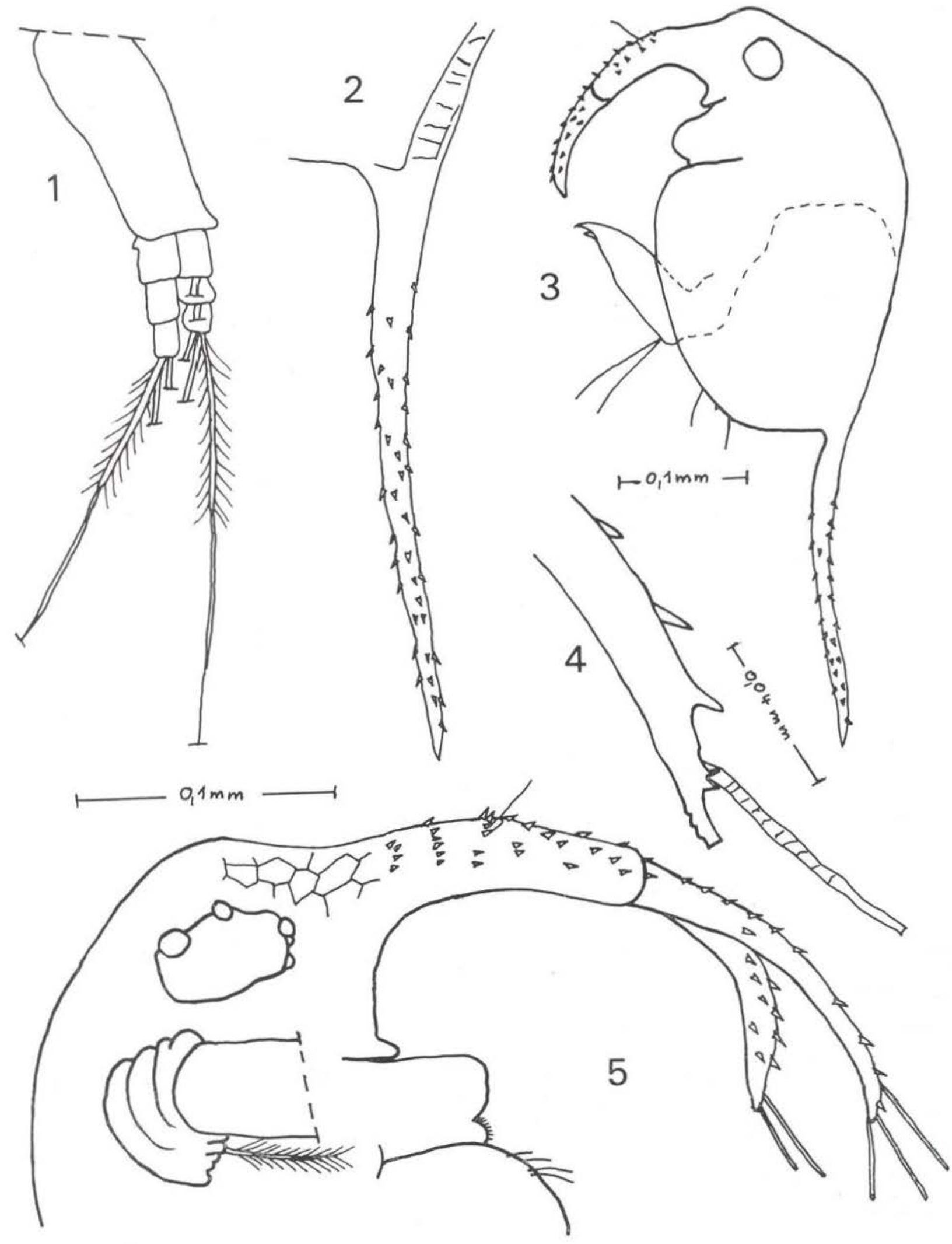

Fig. 1. Bosminopsis negrensis - 1) second antenna; 2) posterior spine; 3) animal total; 4) end of the antennule; 5) head. 
MALE (Fig. 3; Fig. 6)

There are no great differences between the morphology of the male and the female. Evident is the dorsal depression of the shell of the male. Quite different are also the antennules and the first thoracic limb. The very long pair of antennules originate from the anterior end of the ventral margin of the head. The distal end of each antennule bears many short spinules. Near the head on the antennule is a sensory seta and a row of short hairs that follows the longitudinal extension of the antennule. The first $4 / 7$ of the length of the antennules is straight, the tip shows backward.

The first thoracic limb carry a large hook on the distal end of the leg and four setae out of which three are feathered.

\section{DIFFERENTIAL DIAGNOSIS}

Bosminopsis negrensis may be easily distinguished from $B$. deitersi by the presence of the long denticulated posterior spine.
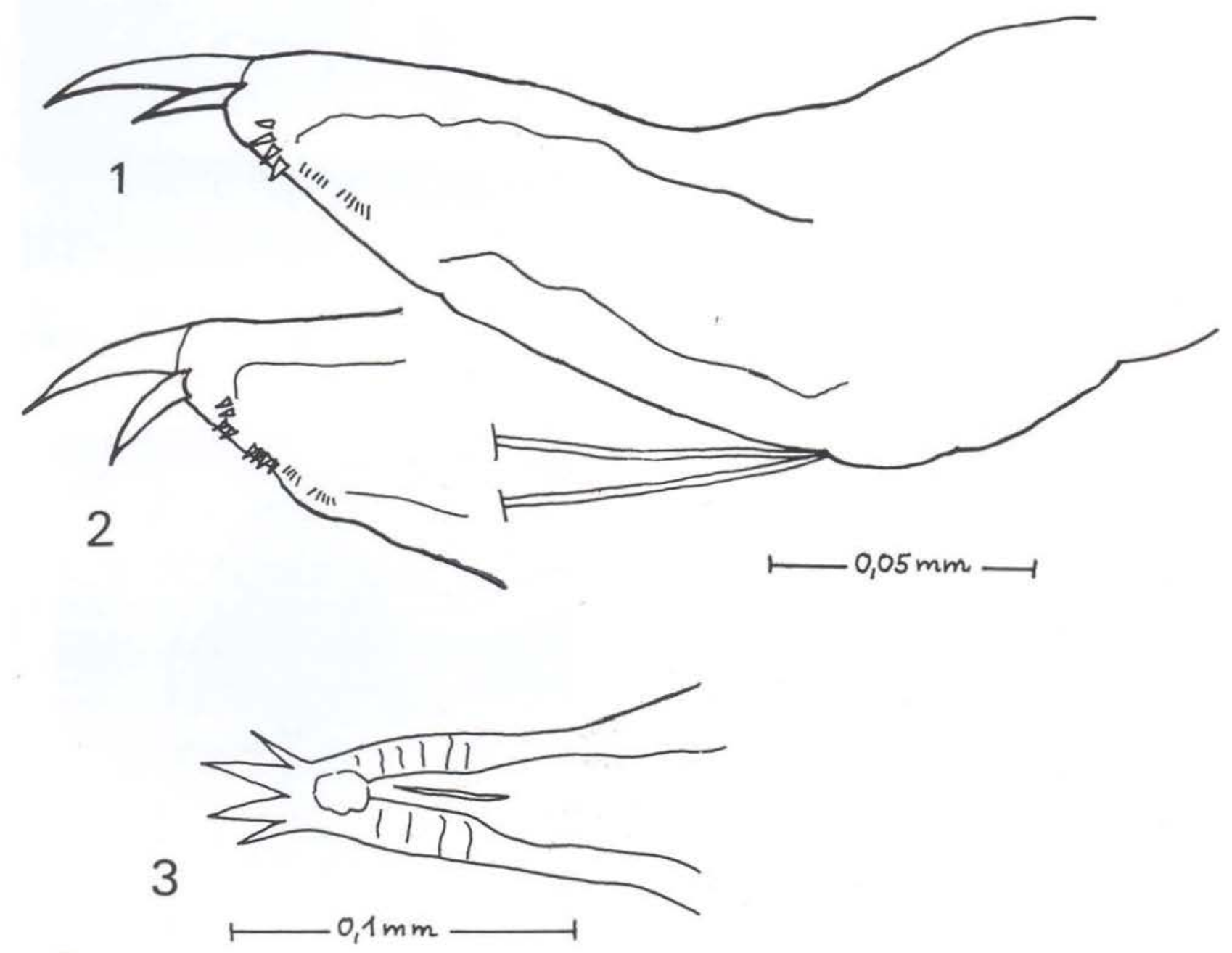

Fig. 2. Bosminopsis negrensis - 1) postabdomen from the left side; 2) end of postabdomen from the right side; 3) postabdomen from ventral. 

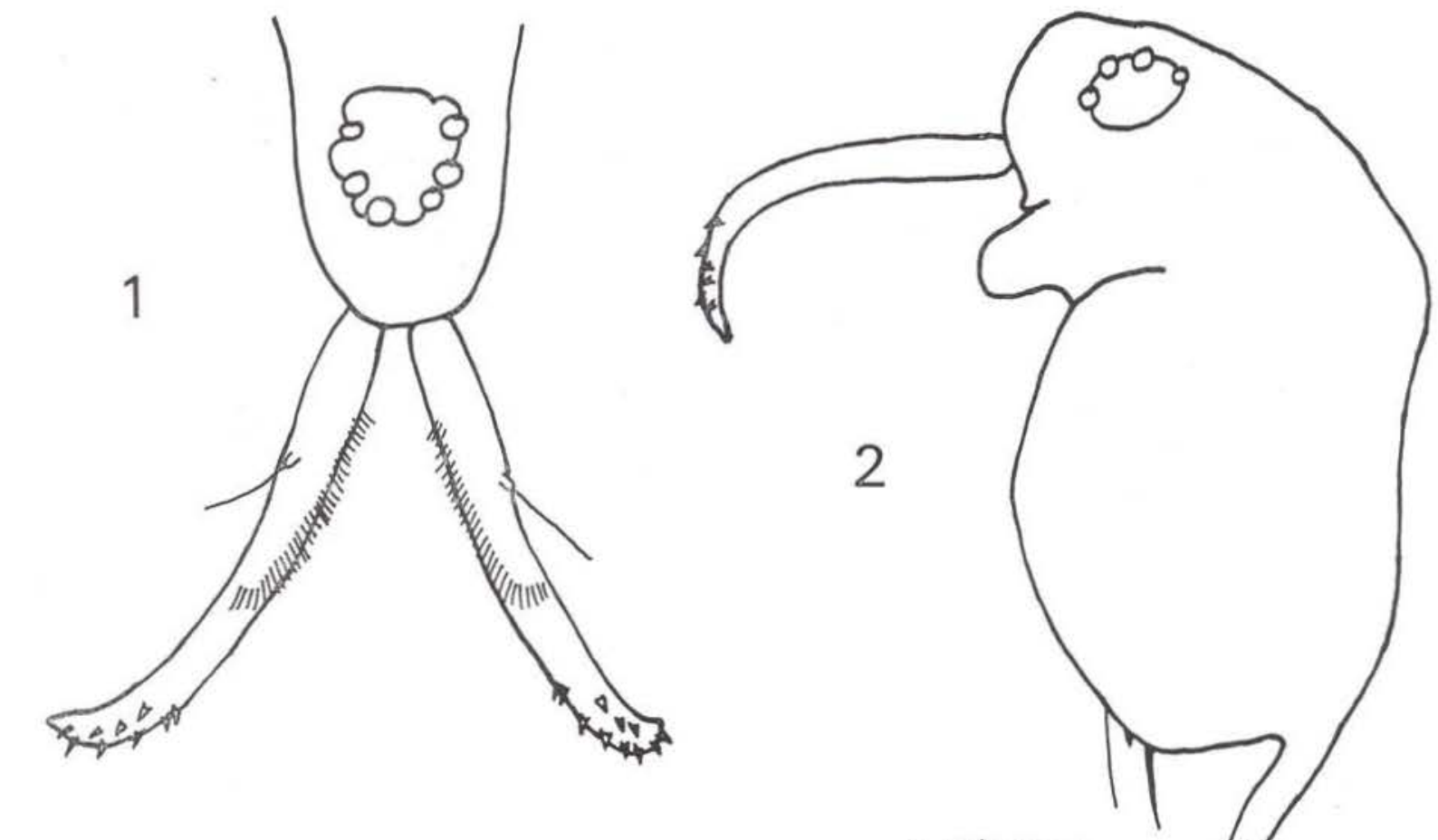

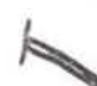
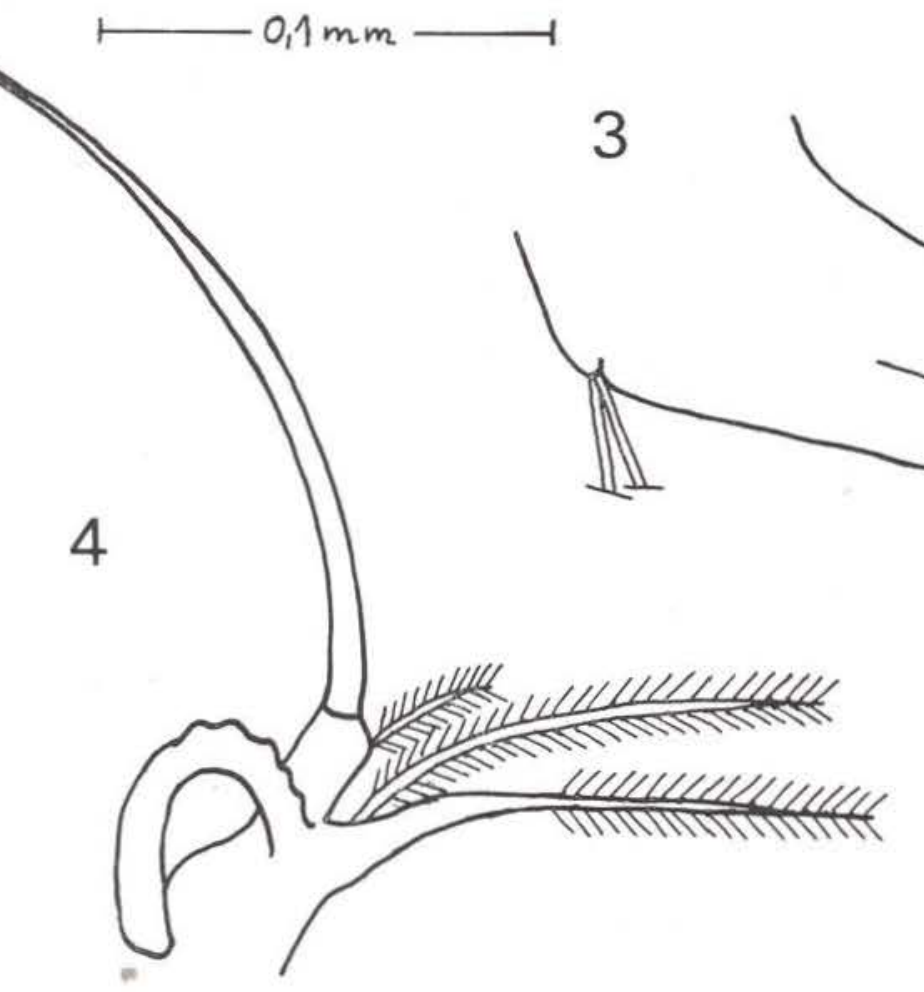

$\vdash 0,1 \mathrm{~mm}^{-1}$

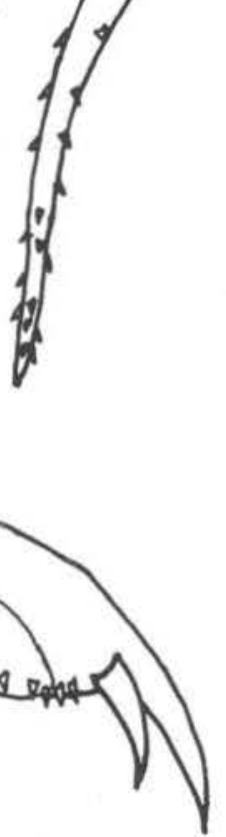

Fig. 3. Bosminopsis negrensis - 1) head with antennules; 2) animal total; 3) postabdomen; 4) first thoracic limb. 


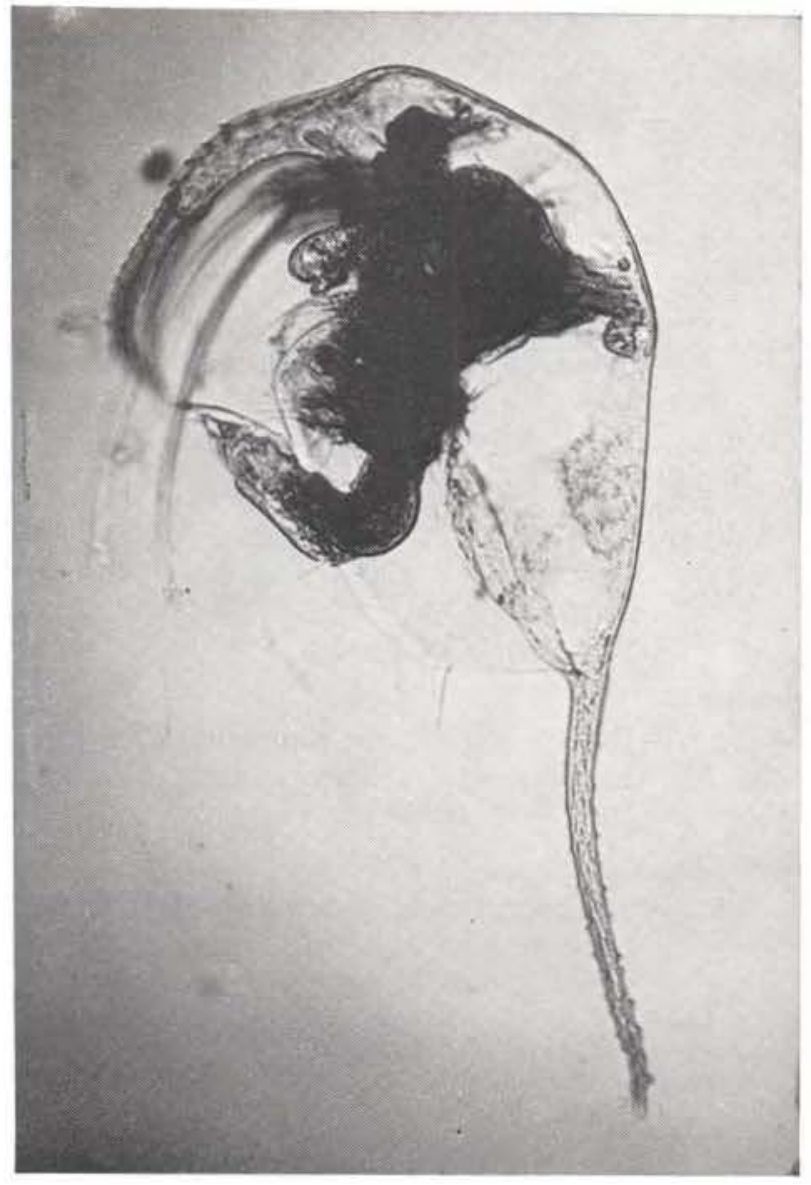

Fig. 4. Bosminopsis negrensis - parthenogenetic female.

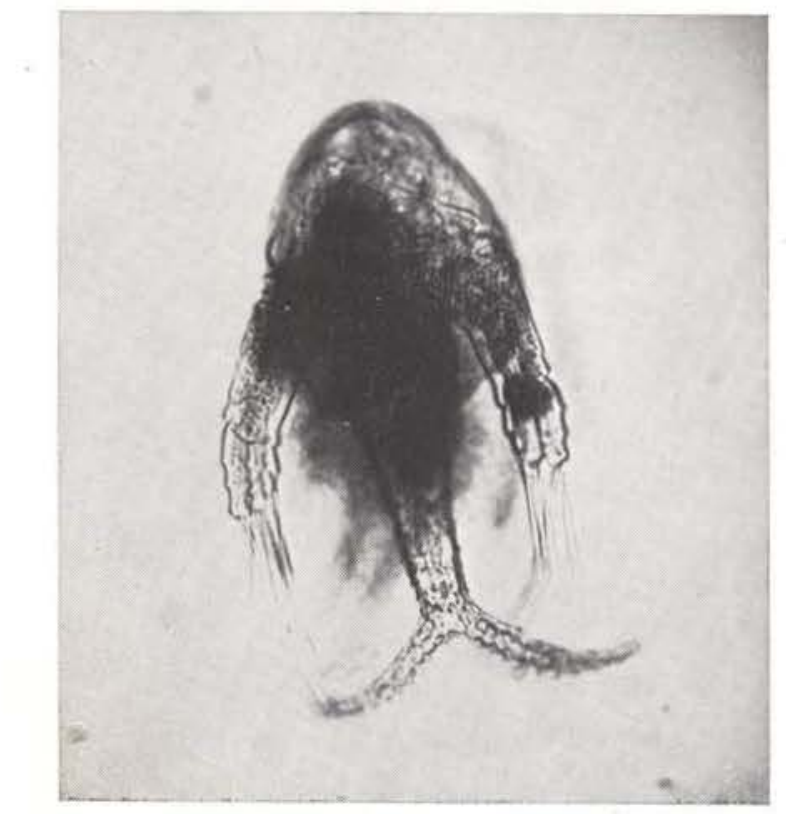

Fig. 5. Bosminopsis negrensis - head of female

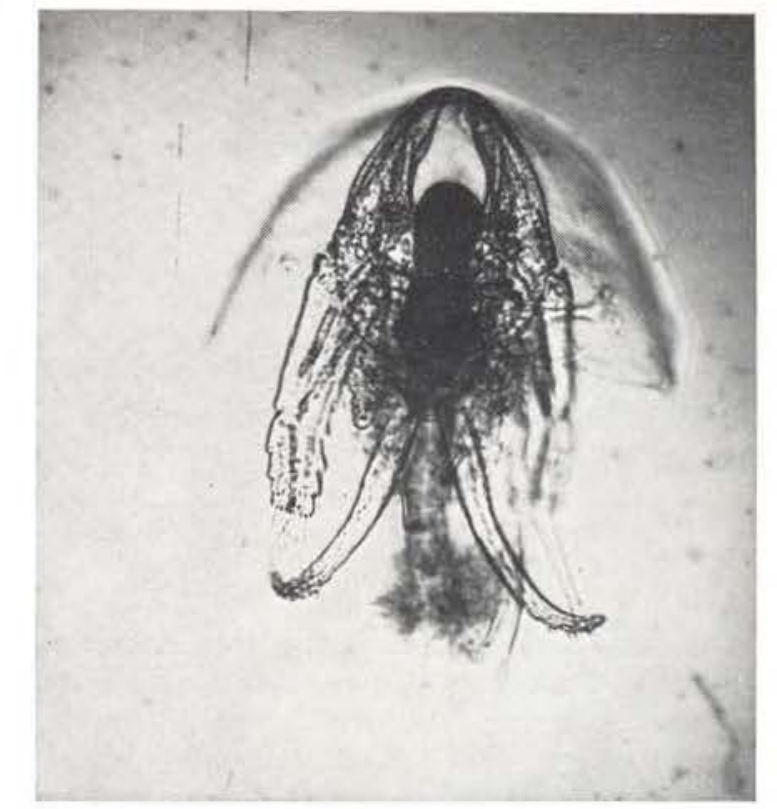

Fig. 6. Bosminopsis negrensis - head of male

\section{Measurements}

According to Flöbner (1972) the following abbreviations are used:

$\mathrm{T}$ Absolute length in $\mu \mathrm{m}$ (head and shell in the longitudinal axis)

$S$ relative length of the shell

$\mathrm{H}$ relative heigth of the shell $A+B$
$C+D$ relative length of the rostrum plus
antennule

$\mathrm{N}$ relative length of the posterior spine

The measurements $\mathrm{S}, \mathrm{H}, \mathrm{A}+\mathrm{B}+\mathrm{C}+\mathrm{D}$, and $\mathrm{N}$ are given in $\% \circ$ of $\mathrm{T}$. In brackets is the number of animals measured. Measurements of B. deitersi from Ueno (1932).

\begin{tabular}{|c|c|c|}
\hline & negrensis 우 우 & deitersi 우우 \\
\hline $\mathrm{T}$ & $275-410 \curvearrowright 341$ (17) & $312-330$ \\
\hline $\mathbf{S}$ & $638-762 \approx 663(14)$ & \\
\hline $\mathrm{H}$ & $586-744 \oslash 647(13)$ & $442-491$ \\
\hline $\begin{array}{l}A+B \\
C+D\end{array}$ & $527-731 \sqsupseteq 625(12)$ & \\
\hline $\mathrm{N}$ & $667-885 \ominus 782(14)$ & \\
\hline
\end{tabular}




\section{OCCURRENCE}

Bosminopsis negrensis was found in the mouthlake of the lower Rio Negro some kilometers up Manaus. It was always associated with B. deitersi.

\section{ACKNOWLEDGEMENTS}

The author thanks Dr. H. V. Herbst, Krefeld, Germany for the help in describing this new species.

\section{Sumário}

Um novo representante do gênero Bosminopsis (Crustacea, Cladocera) é aqui descrito. Até então uma única espécie era conhecida: Bosminopsis deitersi Richard, 1895. B. deitersi foi encontrada nos trópicos e subtrópicos, sendo comum nas águas pretas da bacia Amazônica.

A nova espécie descrita no presente trabalho, B. negrensis, foi encontrada no baixo rio Negro a alguns quilômetros acima de Manaus, estando sempre associada a B. deitersi. As duas espécies são facilmente distinguidas uma da outra pela presença de um longo espinho posterior denticulado em B. negrensis.

\section{LITERATURE CITED}

DADAY, E. VON

1903 - Eine neue Cladoceren-Gattung aus der Familie der Bosminiden. Zool. Anz. 26(704) : 594-597.

FLÖSZNER, D.

1972 - Krebstiere, Crustacea. Kiemen- und Blattüßer, Branchiopoda. Fischläuse, Branchiura. Die Tierwelt Deutschlands, 60. Teil, VEB Gustav Fischer Verlag, Jena, 501pp.

Hutchinson, G.E.

1967 - A treatise on limnology. Vol. II. Introduction to lake biology and the limnoplankton. John Wiley \& Sons, New York, 1115pp.

RICHARD, J .

1895 - Description d'un nouveau Cladocere, Bosminopsis deitersi, n.sp., n.gen Bull. Soc. Zool. Fr., Paris, $20: 1-3$.

STINGelin, T.

1904 - Entomostraken, gesammelt von Dr. G. Hagmann im Mündungsgebiet des Amazonas. Zool. Jb. (Syst), Jena, 20:575-590.

UENO, M.

1932 - Contributions to the knowledge of the Cladocera Fauna of China. Int. Rev. ges. Hydrobiol., 27 : 234-251. 